\title{
Stimulus Duration in a Mixed Nerve Conduction Study: Decomposing Sensory Potential
}

\author{
Karma Sinir İletim İncelemesinde Uyarı Süresi: Duyusal Potansiyelinin Ayrıştırılması
}

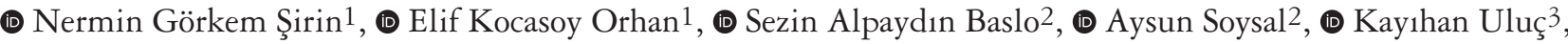 \\ (1) Mehmet Barış Baslo ${ }^{1}$ \\ ${ }^{1}$ Istanbul University, Istanbul Faculty of Medicine, Department of Neurology, Istanbul, Turkey \\ 2University of Health Sciences Turkey, Bakirkoy Prof. Dr. Mazhar Osman Training and Research Hospital for Psychiatric, Clinic of Neurology, \\ Neurologic, and Neurosurgical Diseases, Istanbul, Turkey \\ 3Marmara University Faculty of Medicine, Department of Neurology, Istanbul, Turkey
}

\begin{abstract}
Objective: To decompose a part of the nerve action potential (NAP), mainly originating from large-myelinated sensory fibers, from mixed NAPs by using a stimulus with long duration during surface recordings.

Materials and Methods: Median and ulnar mixed NAPs were elicited using submaximal stimulus intensities with 0.5 and 1.0 -ms stimulus duration, which were adjusted to just below the threshold to activate motor fibers as detected visually through muscle twitch in hand muscles, by stimulating the median and ulnar nerves at the wrist and elbow and recording from the median and ulnar nerves at both the elbow and axilla, respectively. Healthy controls and patients with demyelinating neuropathy and/or motor conduction block were included in the study.

Results: Mixed NAPs were recorded in 24 healthy subjects and three patients who had multifocal motor neuropathy (MMN), acute motor axonal neuropathy (AMAN), and ulnar entrapment neuropathy (UEN). Reference values were calculated in the healthy subjects. In patients with AMAN and MMN, mixed NAPs were normal, whereas in UEN, ulnar mixed NAPs had prolonged latencies.

Conclusion: Mixed NAPs elicited by stimuli with long duration and low strength in the upper limbs can be used to detect sensory involvement at segments where motor conduction block exists and might help to classify demyelinating neuropathies.
\end{abstract}

Keywords: Mixed nerve conduction studies, stimulus duration, surface recording, demyelinating neuropathy, motor conduction block

Öz

Amaç: Bu çalışmada, yüzeyel sinir iletim incelemesinde uzun süreli uyarı kullanılarak, mikst sinir aksiyon potansiyeli (SAP) içerisinde ağılıklı olarak kalın myelinli duyusal liflerden köken alan SAP parçasının ayrıştırılması amaçlanmıştır.

Gereç ve Yöntem: Medyan ve ulnar mikst SAP yanıtları bilekte ve dirsekte medyan ve ulnar sinir üzerine 0,5 ve 1,0 ms uyarı süresi ve submaksimal uyarı şiddeti kullanılarak kaydedildi. Submaksimal uyarı şiddeti, medyan ve ulnar sinir innervasyonlu distal el kaslarında görsel olarak kas kasılması izlenmeyen en yüksek uyarı şiddeti olarak belirlendi. Yüzeyel kayıt elektrotları sırasıyla dirsek ve aksillada medyan ve ulnar sinir trasesi üzerine yerleştirildi. Sağlıklı kontroller ve demiyelinizan nöropatili ve/veya motor ileti bloklu hastalar çalışmaya dahil edildi.

Bulgular: Mikst SAP’ler 24 sağlıklı kontrol ve multifokal motor nöropati (MMN), akut motor aksonal nöropati (AMAN) ve ulnar tuzak nöropatisi (UTN) olan 3 hastada kaydedildi. Referans değerleri sağlıklı kontrollerde hesaplandı. AMAN ve MMN tanılı hastalarda mikst SAP'ler normal olarak izlenirken, UTN olan hastada uzun latanslı olarak kaydedildi.

Sonuç: Düşük uyarı şiddeti ve uzun süreli uyarı ile kaydedilen mikst SAP’ler motor ileti bloğunun bulunduğu segmentlerde duyusal tutuluşu göstermek amacıyla kullanılabilir. Bu ileti incelemeleri demiyelinizan nöropatilerin sınıflandırılmasında fayda sağlayabilir.

Anahtar Kelimeler: Mikst sinir ileti incelemeleri, uyarı süresi, yüzeyel sinir ileti incelemeleri, demyelinizan nöropati, motor ileti bloğu

Address for Correspondence/Yazışma Adresi: Nermin Görkem Şirin MD, Istanbul University, Istanbul Faculty of Medicine, Department of Neurology, Istanbul, Turkey

Phone: +90 2124142000 E-mail: gorkemsirin@yahoo.com.tr ORCID: orcid.org/0000-0001-8792-2929

Received/Geliş Tarihi: 03.12 .2019 Accepted/Kabul Tarihi: 30.08 .2020

${ }^{\circ}$ Copyright 2020 by Turkish Neurological Society

Turkish Journal of Neurology published by Galenos Publishing House. 


\section{Introduction}

It is important to classify demyelinating neuropathies because of the different treatment strategies, follow-up procedures, and prognoses (1). Sensory abnormalities detected by clinical and/or electrophysiologic findings remains as an important hallmark in the classification of both acute and chronic neuropathies $(2,3)$. In the early stages of patients with demyelinating neuropathies, showing mainly conduction block in electrophysiologic studies, this discrimination is crucial because of the different prognoses and response to immunotherapies of the subtypes of these neuropathies. However, in the case of intermediate motor conduction block and normal sensory conduction studies in distal segments, sensory nerve conduction studies in the segment of conduction block might be difficult due to some technical limitations caused by temporal dispersion and artifacts.

In mixed nerve conduction studies, responses are combined from both large myelinated nerve fibers, mostly afferent and efferent nerve fibers of muscle and small myelinated nerve fibers $(4,5)$. No special technique exists to decompose the recorded signal in mixed nerve conduction studies by surface recording. In our opinion, stimulating a mixed nerve with long-duration but lowstimulus intensity recruits large myelinated sensory fibers before the motor fibers do and might be used for this purpose.

In this study, we performed mixed nerve conduction studies with surface recording in the upper extremities using the $\mathrm{H}$ reflex stimulus paradigm $(6,7,8)$. It is hypothesized that the nerve action potential (NAP) of large myelinated sensory fibers can be extracted from mixed NAPs by applying long-duration but low-intensity stimulus. The technique and hypothesis were investigated in a few patients with motor conduction block.

\section{Materials and Methods}

Twenty-four healthy controls aged between 25 and 47 years were recruited to the study. Three patients were examined including one with acute motor axonal neuropathy (AMAN), one with multifocal motor neuropathy (MMN), and one with ulnar nerve entrapment neuropathy (UEN).

Electrophysiologic tests were performed at the bilateral median and ulnar nerves of healthy controls (48 arms). In the patients, mixed NAPs were recorded from the segments where the motor conduction block existed. Each nerve was stimulated at the wrist and elbow and recorded using surface electrodes, and from the elbow $(23 \mathrm{~cm}$ for median and $25 \mathrm{~cm}$ for ulnar nerve proximally from stimulation point, Figure 1) and axilla $(15 \mathrm{~cm}$ for median and $16 \mathrm{~cm}$ for ulnar nerve proximally from stimulation point), respectively. Sensory NAPs were also recorded from the second and fifth digit simultaneously using surface ring electrodes to confirm the stimulation of sensory fibers. For each stimulation point, three stimuli with different durations were applied. The first stimulus with $0.1-\mathrm{ms}$ duration was arranged to elicit a response with
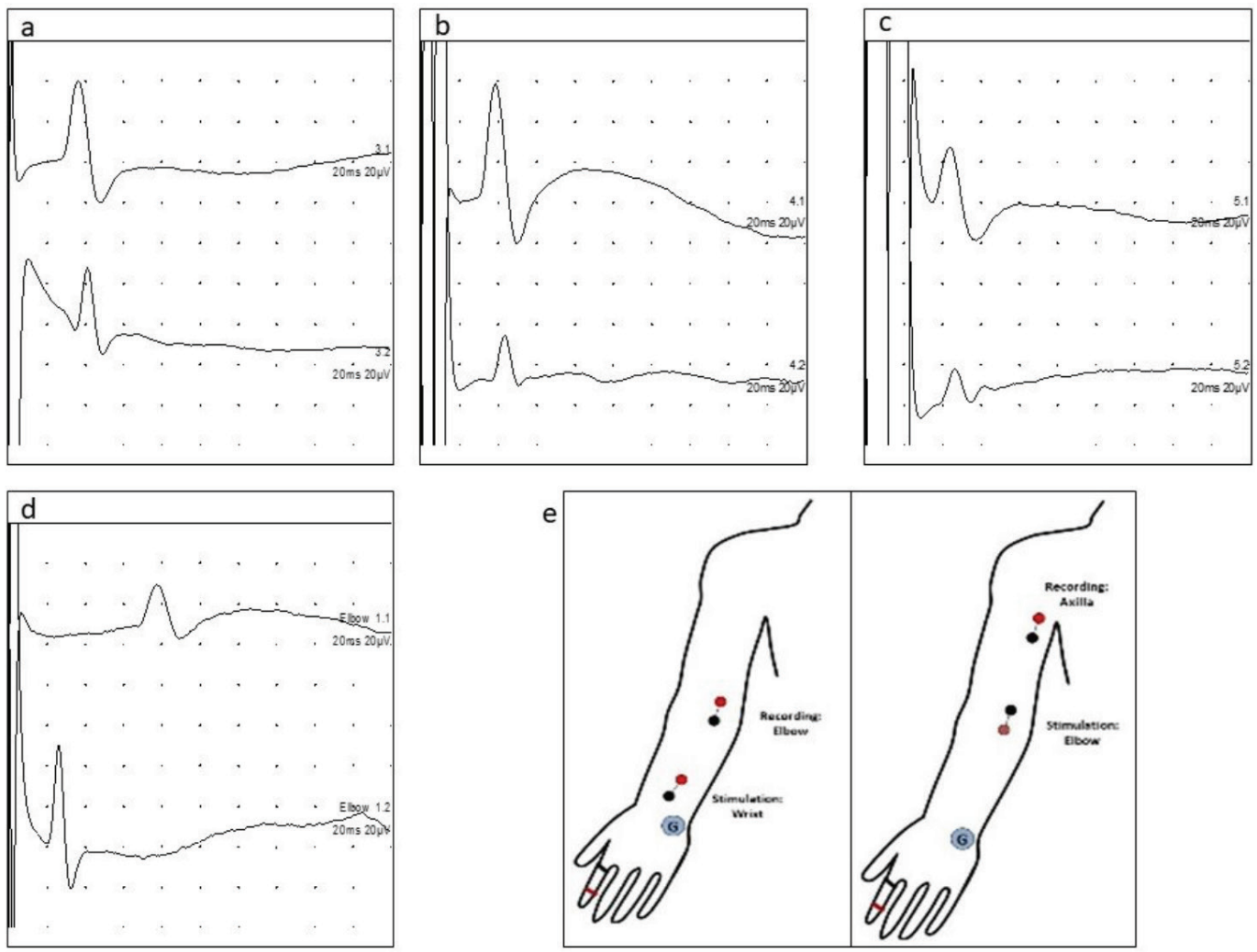

Figure 1. Median mixed nerve action potentials (NAP) recorded in a healthy control. The first trace shows sensory nerve action potential recorded from the second digit, and the second trace is the mixed NAP in each recording. Sensory and mixed NAPs are elicited by stimuli applied at the wrist with 0.1 (a), 0.5 (b) and 1.0 (c) ms duration. In (d), the median nerve is stimulated at the elbow with submaximal strength and long duration (0.5 ms). Note that the sensory NAP appears with longer peak latency compared with the mixed NAP when stimulated at the elbow. (e) shows the electrodes placed for the median nerve study 
maximum amplitude. The second and third stimuli with durations of 0.5 and $1.0 \mathrm{~ms}$, respectively, were adjusted to the highest intensity without any muscle twitch visually observed in distal hand muscles (9). The traces were averaged for 5-10 times until a response with a clear onset and negative peak point appeared. Peak latencies and peak-to-peak amplitudes were calculated for each response.

\section{Statistical Analysis}

The mean and standard deviation of the latencies and amplitudes of the responses were calculated by using the SPSS version 21.0 software (IBM, Armonk, New York). For the latencies of the responses, the upper normal limit was calculated using the mean value added by two standard deviations. Values lower than the lowest normal value were considered abnormal for the amplitude of the responses (5). This study was approved by the local Ethics Committee of Istanbul University, Istanbul Faculty of Medicine (number: 373, date: February 19th, 2014) and all subjects gave informed consent.

\section{Results}

\section{Healthy Controls}

The mean amplitudes and latencies of NAPs recorded from the elbow and axilla, and the stimulus intensities used to elicit them are summarized in Table 1 . The lowest normal values of NAP amplitudes were 8.0, 2.0, and $2.0 \mu \mathrm{V}$ for $0.1,0.5$, and 1.0ms stimulus duration, respectively, in the forearm segment of the median nerve, and 3.0,0.2, and $0.4 \mu \mathrm{V}$ in the arm segment of the median nerve. In the ulnar nerve, the lowest normal values of NAP amplitudes in the forearm and arm segments were $8.0 \mu \mathrm{V}$ for both for $0.1-\mathrm{ms}$ stimulus duration, $1.0 \mu \mathrm{V}$ for both for 0.5 -ms stimulus duration, and 2.4 and $0.4 \mu \mathrm{V}$ for $1.0-\mathrm{ms}$ stimulus duration. In the forearm segment, the upper limits of latencies of NAPs were 4.9 and $6.0 \mathrm{~ms}$ for $0.1-\mathrm{ms}$ stimulus duration, 5.3 and $5.7 \mathrm{~ms}$ for 0.5 -ms duration, and 5.6 and $6.2 \mathrm{~ms}$ for $1.0-\mathrm{ms}$ duration in the median and ulnar nerve, respectively. In the arm segment, the upper limits of latencies were 3.2 and $3.9 \mathrm{~ms}$ for 0.1 -ms stimulus duration, 3.5 and $4.0 \mathrm{~ms}$ for $0.5-\mathrm{ms}$ stimulus duration, and 4.1 and $4.9 \mathrm{~ms}$ for $1.0-\mathrm{ms}$ stimulus duration in the median and ulnar nerves, respectively. The mean latencies of NAPS were increased with longer stimulus duration as expected.

The mean stimulus intensities were $29.4 \pm 6.1,4.3 \pm 2.1$, and $3.2 \pm 1.6 \mathrm{~mA}$ for the median nerve at the wrist, and $28.5 \pm 6.5$, $4.3 \pm 2.5,3.2 \pm 1.8 \mathrm{~mA}$ for the median nerve at the elbow for 0.1 , 0.5 , and $1.0-\mathrm{ms}$ stimulus durations, respectively. For the ulnar nerve at the wrist, the $26.3 \pm 4.6 \mathrm{~mA}$ mean stimulus strength was applied for $0.1 \mathrm{~ms}$ and $3.1 \pm 1.9 \mathrm{~mA}$ for $0.5 \mathrm{~ms}$ and $2.3 \pm 1.5 \mathrm{~mA}$ for 1-ms stimulus duration. For the ulnar nerve at the elbow, the mean stimulus strength for $0.1,0.5$, and 1 -ms stimulus duration were $25.5 \pm 4.4,2.2 \pm 1.1$, and $1.6 \pm 1.0 \mathrm{~mA}$, respectively.

\section{Patients}

\section{Patient 1}

An 18-year-old female patient was admitted to the emergency department with weakness in the lower extremities for a week. Her neurologic examination revealed distal dominant quadriparesis with no sensory dysfunction and normal tendon reflexes. Electromyography (EMG) was performed on the first day of admission, which showed motor conduction block in the right median and bilateral tibial nerves with normal sensory nerve conduction studies (Figure 2). She was diagnosed as having Guillain-Barre syndrome and had intravenous immunoglobulin (IVIG) infusion for 5 days. After 2 months, she had a full clinical recovery. In a follow-up EMG study, the motor conduction blocks had disappeared without temporal dispersion and distal motor amplitudes were still normal, a finding in favor of "reversible conduction failure" that is seen in AMAN. In the first EMG study where the motor conduction blocks were present, NAP studies of bilateral median nerves showed normal and symmetrical values (Figure 2, Table 2).

\section{Patient 2}

A male patient aged 58 years who had numbness in the fifth digit of the left hand for one month was referred to the EMG laboratory with a suspected diagnosis of ulnar nerve entrapment at the elbow. A motor conduction study of the ulnar nerve showed

Table 1. Amplitudes and latencies of mixed nerve action potentials and stimulus intensities used to elicit them

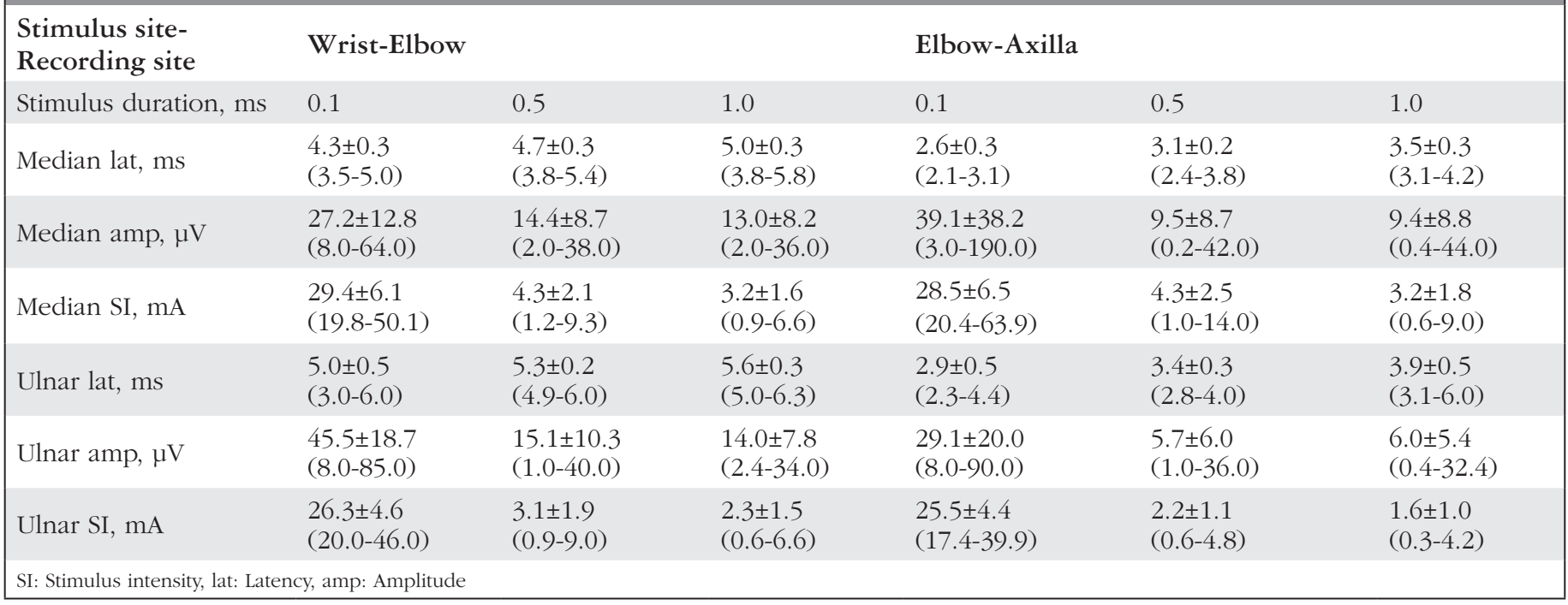


partial conduction block between above and below the elbow sites with a normal orthodromic sensory nerve conduction study in the fifth digit. An inching study revealed prolonged latency between 1 and $2 \mathrm{~cm}$ distal to the medial epicondyle. NAP studies of the ulnar nerve recorded from the elbow revealed prolonged latencies (Figure 3, Table 3).

\section{Patient 3}

A 32-year-old male patient had weakness in both legs for two years without any sensory symptoms. A needle EMG study showed bilateral L3-S1 motor neuronopathy. After one year, he improved gradually. Six months later, he experienced difficulty in picking up

Table 2. Mixed NAPs of patient 1 with acute motor axonal neuropathy with reversible conduction block

\begin{tabular}{llllll|}
$\begin{array}{l}\text { Stimulus site- } \\
\text { Recording site }\end{array}$ & \multicolumn{2}{l}{ Wrist-Elbow } & \multicolumn{2}{l}{ Elbow-Axilla } \\
& Lat, ms & Amp, $\mu \mathrm{V}$ & Lat, ms & Amp, $\mu \mathrm{V}$ \\
R median, 0.1 & 3.9 & 36.0 & 2.3 & 36.0 \\
R median, 0.5 & 4.1 & 32.4 & 2.6 & 40.0 \\
R median, 1.0 & 4.3 & 24.0 & 3.0 & 19.2 \\
L median, 0.1 & 3.9 & 48.0 & 2.2 & 12.0 \\
L median, 0.5 & 4.1 & 45.0 & 2.7 & 12.4 \\
L median, 1.0 & 4.2 & 40.0 & 2.9 & 16.8 \\
NAP: Nerve action potential, Lat: Latency, Amp: Amplitude
\end{tabular}
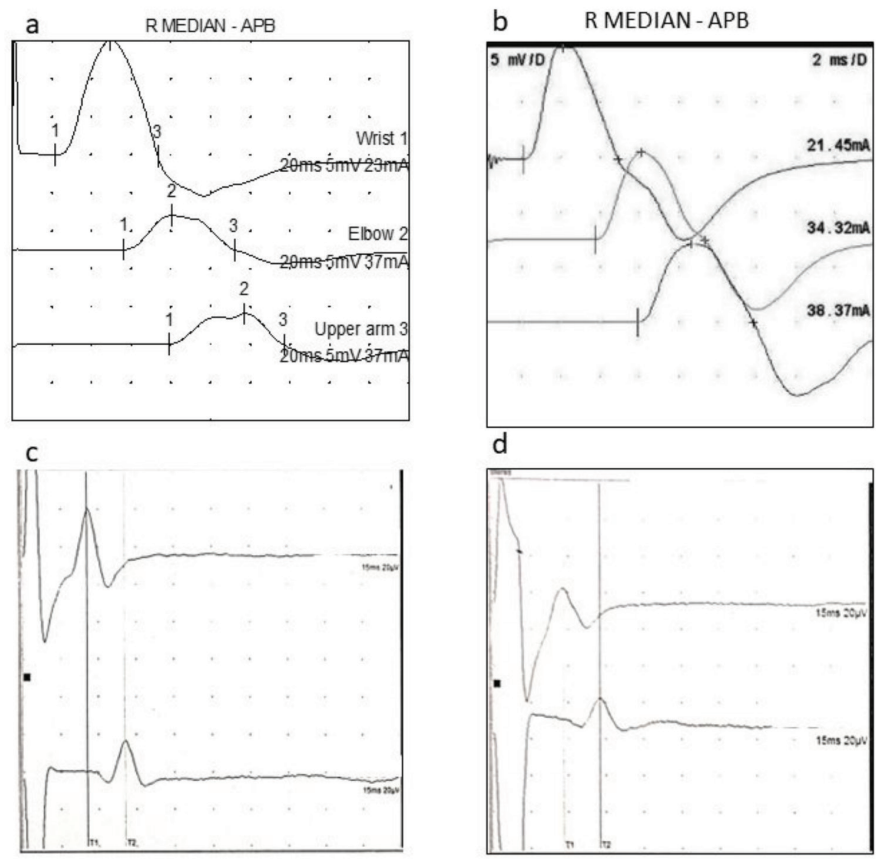

Figure 2. Nerve conduction studies of patient 1 with acute motor axonal neuropathy. Motor conduction block at the forearm segment (a) in the median nerve resolved in the second study two months after onset (b) compatible with reversible conduction failure. Normal mixed NAPs elicited by stimuli with $0.5 \mathrm{~ms}$ (c) and $1.0 \mathrm{~ms}$ (d) were recorded by wrist stimulation

NAPs: Nerve action potentials objects with the fingers of the right hand, and after two months he felt weakness in the left hand and the weakness in the right hand had worsened. His neurologic examination revealed bilateral weakness in interosseus, finger flexors, and abductor pollicis brevis muscles predominantly on the right side. Deep tendon reflexes were normal and no sensory abnormalities were detected in an examination. A second EMG study revealed bilateral motor conduction block in the median nerves at the wrist-elbow segment on the left side, and at the elbow-axilla segment on the right side with normal orthodromic sensory conduction studies. The patient was diagnosed as having MMN. Cerebrospinal fluid tests and antiGM1 antibody results were normal. After one course of IVIG,

Table 3. Mixed NAPs of patient 2 with ulnar entrapment neuropathy on the left side

\begin{tabular}{|c|c|c|c|c|}
\hline \multirow{2}{*}{$\begin{array}{l}\text { Stimulus site- } \\
\text { Recording site }\end{array}$} & \multicolumn{2}{|c|}{ Wrist-Elbow } & \multicolumn{2}{|c|}{ Elbow-Axilla } \\
\hline & Lat, ms & Amp, $\mu \mathrm{V}$ & Lat, ms & Amp, $\mu \mathrm{V}$ \\
\hline L ulnar, 0.1 & $7.0^{*}$ & 32.0 & 3.0 & 50.0 \\
\hline L ulnar, 0.5 & $7.4^{*}$ & 6.0 & 3.3 & 16.0 \\
\hline L ulnar, 1.0 & $7.6^{*}$ & 6.0 & 3.6 & 8.0 \\
\hline
\end{tabular}

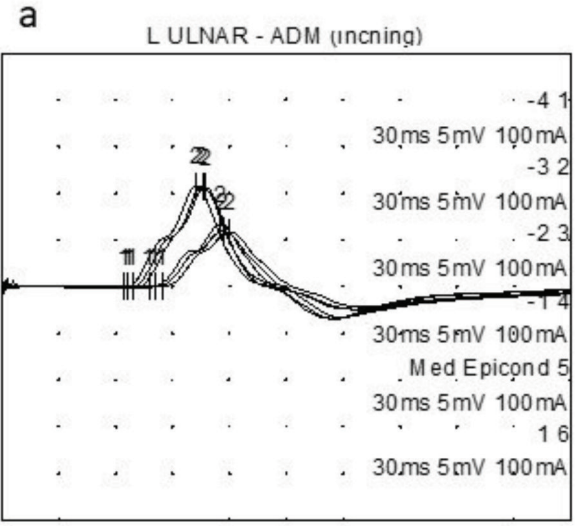

b

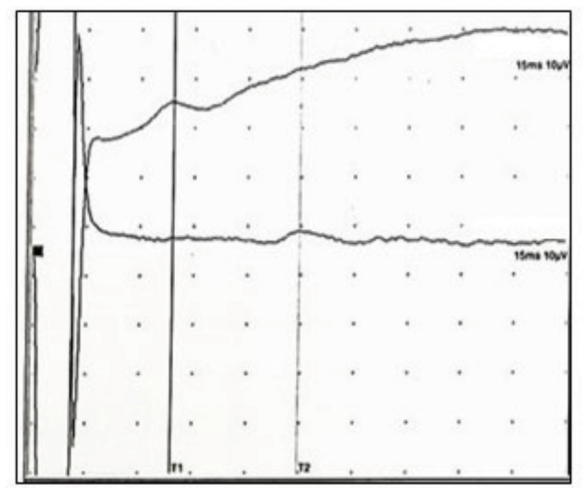

Figure 3. Ulnar inching study revealed motor conduction block between 1 and $2 \mathrm{~cm}$ distal to the medial epicondyle in patient 2 (a) with a mixed NAP with prolonged peak latency (b)

NAP: Nerve action potential 
his weakness was improved. The mixed NAPs were performed in median nerves bilaterally and were found as normal (Table 4).

\section{Discussion}

In this study, mixed NAPs were recorded at the forearm and arm segment using stimuli with long duration and low strength to activate large myelinated sensory fibers preferentially. These mixed NAPs elicited with long-stimulus duration might be used in testing sensory fibers at proximal segments.

In demyelinating neuropathies, routine sensory nerve conduction studies, which are commonly restricted to distal segments, are inadequate for detecting sensory fiber involvement if demyelination occurs more proximally in the intermediate segments of the arm. Sensory NAP recorded antidromically across proximal segments can be used in such conditions; however, there are some limitations. First, the stimulation of a mixed nerve at high strengths causes muscle artifact, which complicates the study. Second, in sensory-motor demyelinating polyneuropathies, sensory responses recorded from the digits are either absent or very small, limiting their use in proximal segments $(10,11)$. Although the present diagnostic guidelines for demyelinating neuropathies give place to sensory nerve conduction studies only as supportive criteria, these guidelines mainly aim to detect the presence of demyelinating, but not to differentiate the subtypes of these neuropathies. However, it is important to do so, because these neuropathies do not share the same features regarding the prognosis and response to therapy. Mixed NAPs have the potential for discriminating acute or chronic axonal neuropathies (AMAN and $\mathrm{MMN}$ ) from sensorimotor demyelinating neuropathies.

Mixed NAPs were previously studied in chronic demyelinating polyneuropathy with and without paraproteinemia (12). In this particular study, mixed NAPs were elicited with stimulus strength just below the threshold to activate motor fibers. The results revealed reduced conduction velocities and amplitudes and increased temporal dispersion in the patients (12).

In our patients with AMAN and MMN, motor conduction studies revealed conduction block. These patients had normal mixed NAP studies where the motor conduction block was located. However, in a patient with ulnar entrapment neuropathy, NAP latencies were prolonged in the forearm segment of the ulnar nerve concordant with the inching study, showing motor conduction slowing at $1-2 \mathrm{~cm}$ proximal to the medial epicondyle. When considered from this view, mixed

\begin{tabular}{|lcccc|}
\hline $\begin{array}{l}\text { Table 4. Mixed NAPs of patient } 3 \\
\text { neuropathy }\end{array}$ & \multicolumn{3}{l|}{ with multifocal motor } \\
$\begin{array}{l}\text { Stimulus site- } \\
\text { Recording site }\end{array}$ & Wrist-Elbow & \multicolumn{2}{l|}{ Elbow-Axilla } \\
& Lat, ms & Amp, $\mu \mathrm{V}$ & Lat, ms & Amp, $\mu \mathrm{V}$ \\
R median, 0.1 & 3.7 & 13.0 & 2.2 & 37.5 \\
R median, 0.5 & 4.5 & 12.5 & 2.2 & 2.5 \\
R median, 1.0 & 5.0 & 7.5 & 2.6 & 2.5 \\
L median, 0.1 & 4.4 & 12.0 & 2.4 & 17.5 \\
L median, 0.5 & 4.7 & 5.0 & 2.9 & 5.0 \\
L median, 1.0 & 5.0 & 5.0 & 3.3 & 2.5 \\
\hline
\end{tabular}

NAPs elicited by long-stimulus duration seem to indicate sensory fiber involvement in UEN. However, another aspect relies on normal mixed NAPs in AMAN and MMN, suggesting that these conduction studies might be used in the diagnosis of these neuropathies.

A previous study focused on the effect of stimulus duration in mixed NAPs (9). In this study, mixed NAPs, which consisted of $50 \%$ of the supramaximal response, were recorded from the median nerve by stimulating with different durations. Their results revealed that, as stimulus duration became longer, the latencies of mixed NAPs were prolonged when subthreshold stimulus strengths were applied (9). Similarly, our results also showed that the latencies of mixed NAPs were prolonged with increased stimulus durations. This finding could be explained as follows: with increasing stimulus duration, stimulus intensity becomes lower according to the rheobase curve. Therefore, the current needed for depolarization of the axolemma is reached later, resulting in prolongation of latency of the response. Our study differed from the previous study in that submaximal stimuli were performed to elicit $50 \%$ of the maximum amplitude of mixed NAP in the previous study, whereas we used a stimulus strength just below the threshold to activate motor fibers to stimulate larger myelinated sensory fiber preferentially, much lower than in the prior study.

This method is easy, painless, and performed with surface electrodes without any need for special equipment. However, the low amplitudes recorded from the axilla might limit their use. Furthermore, the latencies of mixed NAPs are more consistent than the amplitudes. Taking these into account, it might be conceivable to use latencies in the detection of demyelination of peripheral nerves.

The contribution of the response coming from motor fibers could also be monitored through surface recordings. However, in this study, we did not record the motor response of the hand muscles innervated by the median and ulnar nerve, instead we preferred to trace motor recruitment by inspecting muscle twitches visually for a few reasons. By using surface recordings, the muscle fibers located deeply were missed, and by needle recording, only a small area can be detected, restricted by the recording area of needle electrode. In addition, it is hard to record all intrinsic hand muscles innervated by the ulnar and median nerves. As a result, the contribution of motor responses to mixed NAPs could not be excluded. Another limitation of our study was the small number of patients.

\section{Conclusion}

In this study, mixed NAPs comprising predominantly sensory fibers were recorded at the proximal segments where motor conduction block may occur. These mixed conduction studies may help to distinguish MMN or AMAN from other demyelinating neuropathies. Further studies are needed to explore these mixed NAPs in acute and chronic demyelinating polyneuropathies.

\section{Ethics}

Ethics Committee Approval: This study was approved by the local Ethics Committee of Istanbul University, Istanbul Faculty of Medicine (number: 373, date: February 19th, 2014).

Informed Consent: All participants gave written informed consent. 
Peer-review: Externally and internally peer-reviewed.

\section{Authorship Contributions}

Concept: N.G.Ş., E.K.O., M.B.B., Design: N.G.Ş., E.K.O., M.B.B., Data Collection or Processing: N.G.Ş., E.K.O., S.A.B., A.S., K.U., Analysis or Interpretation: N.G.S.., M.B.B., K.U., A.S., Literature Search: N.G.Ş., S.A.B., M.B.B., Writing: N.G.Ş., M.B.B., S.A.B., A.S., K.U.

Conflict of Interest: The authors declare that they have no conflict of interest.

Financial Disclosure: This study was funded by Istanbul University Scientific Research Projects (project number: 40164).

\section{References}

1. Busby M, Donaghy M. Chronic dysimmune neuropathy. A subclassification based upon the clinical features of 102 patients. J Neurol 2003;250:714724.

2. Joint Task Force of the EFNS, the PNS. European Federation of Neurological Societies/Peripheral Nerve Society guideline on management of multifocal motor neuropathy. Report of a joint task force of the European Federation of Neurological Societies and the Peripheral Nerve Society--first revision. J Peripher Nerv Syst 2010;15:295-301.

3. Olney RK, Lewis RA, Putnam TD, Campellone JV Jr, American Association of Electrodiagnostic M. Consensus criteria for the diagnosis of multifocal motor neuropathy. Muscle Nerve 2003;27:117-121.
4. Dumitru ML, Joergensen GH. Logical Connectives Modulate Attention to Simulations Evoked by the Constituents They Link Together. Front Psychol 2018;9:1358

5. Oh SJ. Distinguishing Features of the Repetitive Nerve Stimulation Test Between Lambert-Eaton Myasthenic Syndrome and Myasthenia Gravis, 50Year Reappraisal. J Clin Neuromuscul Dis 2017;19:66-75.

6. Misiaszek JE. The H-reflex as a tool in neurophysiology: its limitations and uses in understanding nervous system function. Muscle Nerve 2003;28:144160.

7. Knikou M. The H-reflex as a probe: pathways and pitfalls. J Neurosci Methods 2008;171:1-12.

8. Zehr EP. Considerations for use of the Hoffmann reflex in exercise studies. Eur J Appl Physiol 2002;86:455-468.

9. Mogyoros I, Kiernan MC, Gracies JM, Burke D. The effect of stimulus duration on the latency of submaximal nerve volleys. Muscle Nerve 1996;19:1354-1356.

10. McCombe PA, Pollard JD, McLeod JG. Chronic inflammatory demyelinating polyradiculoneuropathy. A clinical and electrophysiological study of 92 cases. Brain 1987;110 (Pt 6):1617-1630.

11. Saperstein DS, Katz JS, Amato AA, Barohn RJ. Clinical spectrum of chronic acquired demyelinating polyneuropathies. Muscle Nerve 2001;24:311-324.

12. Luciano CA, Gilliatt RW, Conwit RA. Mixed nerve action potentials in acquired demyelinating polyneuropathy. Muscle Nerve 1995;18:85-92. 